\title{
Laparoscopic repair of lateral sided trocar site hernias
}

\author{
Hasan Ediz Sıkar'(D), Kenan Çetin' (D) \\ ${ }^{1}$ Clinic of General Surgery, Dr. Lütfi Kırdar Kartal Training and Research Hospital, Istanbul, Turkey
}

\begin{abstract}
Objective: Repair of trocar site hernia (TSH) has been mentioned in a limited number of studies. Trocar site hernias are mostly located in the umbilical region with a small size. Laparoscopic repair could be a choice due to the appearance of large defects and requirement of mesh repair for lateral sided TSH. We aimed to share our experience with laparoscopic repair of lateral sided trocar site hernia (LRTSH) with a long term follow up.

Material and Methods: Twenty-three patients who underwent LRTSH between March 2013 and July 2015 were included in our study. Four edges of the mesh were fixed with pre-tied 2/0 polypropylene suture for 9 patients initially (Group 1). Unexpected complication of chronic pain in 3 patients led us to revise our method and we avoided to position the mesh with transabdominal sutures for the rest of the patients (Group 2).

Results: Nineteen (82.6\%) female and 4 (17.4\%) male patients, with a mean age of 50.9 years underwent laparoscopic repair. Following the revision and avoiding transabdominal sutures to position the mesh, no complaint of chronic pain was observed, and the difference was statistically significant between the groups $(p<0.05)$.

Conclusion: Previous laparoscopic surgery indicates the lack of obstacle in laparoscopic repair of TSH, and LRTSH can be considered as first option in treatment. Shorter mean operative time in obese patients and lack of recurrence in our series support this view. Using transabdominal sutures should be avoided to prevent chronic pain in LRTSH.
\end{abstract}

Keywords: Incisional hernia, laparoscopy, surgical mesh

Cite this article as: SIkar HE, Çetin K. Laparoscopic repair of lateral sided trocar site hernias. Turk J Surg 2020; 36 (3): $278-283$

Corresponding Author Hasan Ediz Sıkar

E-mail: hasan.sikar@me.com

Received: 28.01 .2020

Accepted: 27.02 .2020

Available Online Date: 28.09 .2020

(.) Copyright 2020 by Turkish Surgical Society Available online at www.turkjsurg.com

DOI: $10.47717 /$ turkjsurg.2020.4447

\section{INTRODUCTION}

The increase in the number of laparoscopic operations has undesirably led to a rise in trocar site hernias (TSH). Most of the studies consist of the causes and etiology of TSH (1-6). Repair of TSH has been mentioned in a limited number of studies $(7,8)$. Trocar site hernias are mostly located in the umbilical region with a small size, and open approach could be the first choice of treatment for these patients (9-11). In contrast, most of the patients with lateral sided TSH had a defect with a diameter of more than $3 \mathrm{~cm}$ in our series. Blunt dissection with retractors to insert the optical trocar and insufficient closure of the abdominal wall could be the possible cause of this situation (12).

Trocar site hernias are incisional hernias, and laparoscopic repair is one of the treatment options for incisional hernias with decreased recurrence rates and morbidity (13). Laparoscopic repair could be a choice due to the appearance of large defects and requirement of mesh repair for lateral sided TSH. Although there are some case reports for laparoscopic repair of TSH, there is data missing in the literature about this specific topic (14). We aimed to share our experience with laparoscopic repair of lateral sided trocar site hernia (LRTSH) with a long-term follow up.

\section{MATERIAL and METHODS}

Regarding the literature, hernias located laterally from the lateral margin of the rectus sheath are defined as lateral hernias. Thus, hernias located between the lateral borders of the rectus muscle sheath -which were not located over linea alba- were excluded. Twenty-three patients who underwent LRTSH between March 2013 and July 2015 were included in our study. Ultrasonography was used to evaluate the remaining trocar sites before the operation. All operations were performed by the same surgeon in our clinic. The study was approved by our hospital's ethics com- 
mittee (reg. 5141092, 2018). Medical records were reviewed retrospectively from our clinic's database collected prospectively with a follow-up form including patient characteristics and demographics, TSH occurrence time, previous surgery, defect size, mesh size, mesh type, operative time, conversion rate, complications, recurrences and follow-up time.

The patients were positioned supine, and the arm of the opposite side was tucked. All operations were performed with three ports and a 30-degree laparoscope. Ports were placed as far away as from the TSH, in the opposite side of the abdominal wall. The optical port was an 11-mm trocar and was inserted using an open approach. Following the creation of the pneumoperitoneum, two additional trocars of $6 \mathrm{~mm}$ were inserted under direct vision to form a triangle. Most of the patients required adhesiolysis for peritoneal adhesions due to previous operations. Following the measurement of the hernia size, the closest available size of the mesh was used for sufficient overlap in most of the cases - about $5 \mathrm{~cm}$ all around the defect. Parietene Composite (PPC) Mesh (Covidien, Mansfield MA, USA) was used for laparoscopic repair. The mesh was shaped in defects smaller than $4 \mathrm{~cm}$ to avoid unnecessary use. Four edges of the mesh were fixed with pre-tied 2/0 polypropylene suture for 9 patients initially (Group 1). Unexpected complication of chronic pain in 3 patients led us to revise our method, and we avoided positioning the mesh with transabdominal sutures for the rest of patients (Group 2). Titanium helical tacks were used to fix the mesh with double-crown technique for all patients (Figure 1).

All cases were controlled on the postoperative $10^{\text {th }}$ day, sixth week, third month, sixth month and annually. Also, patients with symptomatic seroma were controlled in $8^{\text {th }}$ and $10^{\text {th }}$ week to decide aspiration. Patients were examined with ultrasonography for both hernia site and trocar site annually.
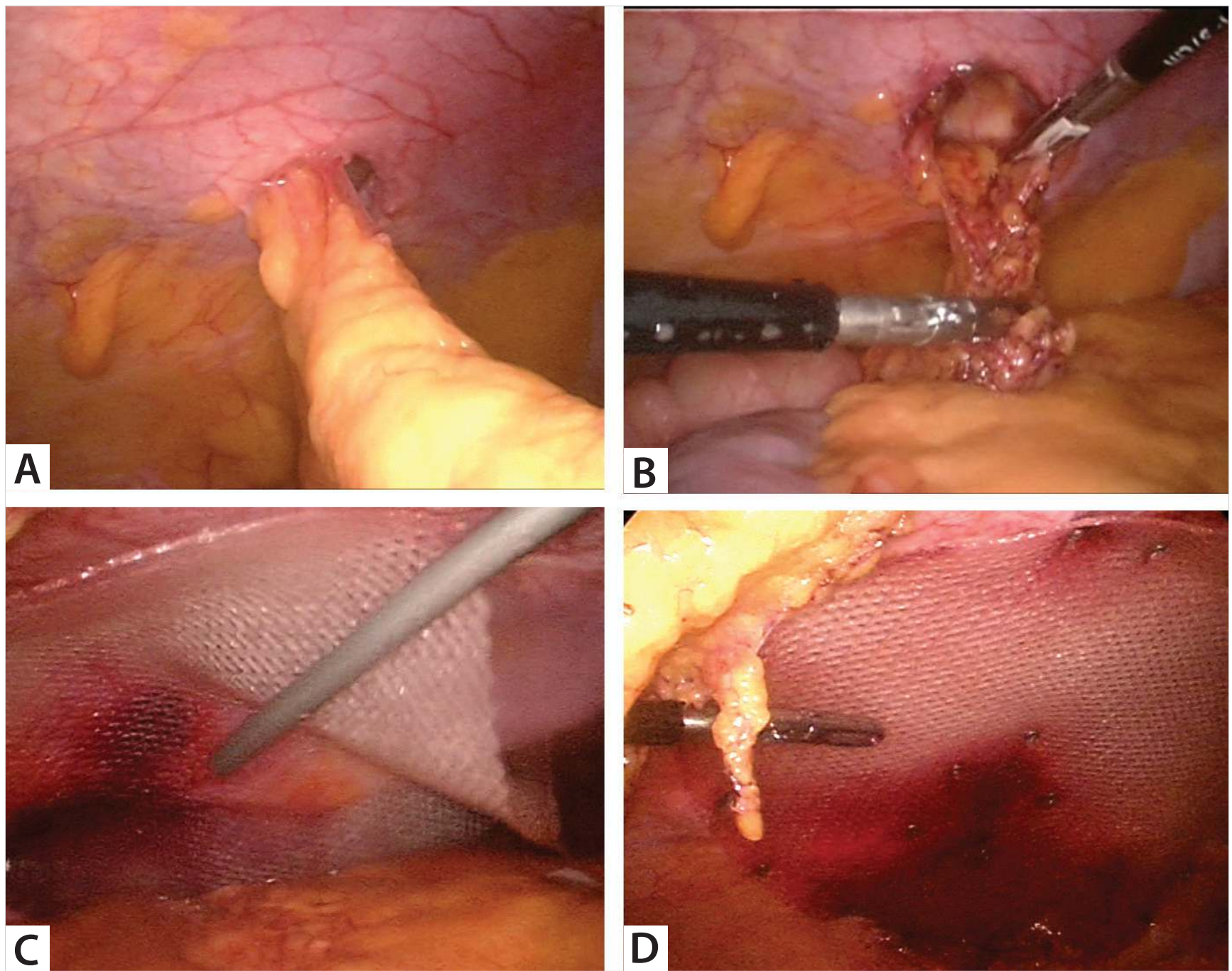

Figure 1. a. Right-sided trocar site hernia following laparoscopic hernia repair, b. Reducing the contents of the hernia, c. Positioning the mesh, d. Double-crown technique. 
An Excel worksheet (Microsoft Corp., Redmond, WA) was used to enter the data. Statistical analysis was carried out using IBM SPSS Statistics ver. 24.0 (IBM Co., Armonk, NY, USA). Descriptive statistical methods (mean, standard deviation, frequency, percent, minimum and maximum) were used to evaluate the study data. Mann-Whitney $U$ test was used to compare quantitative variables without normal distribution. Pearson Chi-square test and Fisher's exact test were used to compare qualitative data. Based on the results of the analyzes, $p$-value $<0.05$ was considered to be statistically significant.

\section{RESULTS}

A total of 23 patients, 19 (82.6\%) females and 4 (17.4\%) males, with a mean age of 50.9 years underwent laparoscopic repair. Most of the patients were obese, and mean BMI was $30.7 \mathrm{~kg} / \mathrm{m}^{2}$. Mean number of previous operations was 2.1. All patients were admitted with symptoms within 1 year following surgery, and mean TSH occurrence time was 6.1 months. Twenty-two (95.7\%) of the TSH had occurred from $10 \mathrm{~mm}$ or larger trocars. The patient with hysterectomy had 2 hernias side by side that occurred from $5 \mathrm{~mm}$ trocars. Operation notes were examined, and insertion of large drain tubes from both trocars could be explanatory for this atypical condition. Nine (39.1\%) of the patients had previous laparoscopic surgery in our clinic. Most common type

\begin{tabular}{|l|c|}
\hline \multicolumn{2}{|l|}{ Table 1. Characteristics of the patients } \\
\hline Parameter & Value \\
\hline Age & $50.9 \pm 10.3$ \\
\hline Sex (female/male) & $19(82.6 \%) / 4(17.4 \%)$ \\
\hline BMI (kg/m ${ }^{2}$ ) & $30.7 \pm 4.8$ \\
\hline Smoking & $3(13.1 \%)$ \\
\hline Comorbid disease & $17(73.9 \%)$ \\
\hline Region (right/left) & $12(52.2 \%) / 11(47.8 \%)$ \\
\hline TSH occurrence time (months) & $6.1 \pm 2.2$ \\
\hline Follow up time (months) & $50.5 \pm 7$ \\
\hline Defect size (cm $\left.{ }^{2}\right)$ & $16.3 \pm 12.3$ \\
\hline Mesh size (cm $\left.{ }^{2}\right)$ & $219.8 \pm 58.2$ \\
\hline Operative time (min) & $51.5 \pm 7.4$ \\
\hline Number of previous operations & $2.1 \pm 1.4$ \\
\hline Type of previous operation & \\
LAHR & $8(34.8 \%)$ \\
Colorectal & $5(21.7 \%)$ \\
Bariatric & $3(13 \%)$ \\
Nephrectomy & $3(13 \%)$ \\
Splenectomy & $2(8.7 \%)$ \\
Adrenalectomy & $1(4.3 \%)$ \\
Hysterectomy & $1(4.3 \%)$ \\
\hline BME Body mass & \\
\hline
\end{tabular}

*BMI: Body mass index; TSH: Trocar site hernia; LAHR: Laparoscopic abdominal hernia repair. of previous operation was laparoscopic abdominal hernia repair (LAHR) - 8 (34.8\%) of the patients. Characteristics of the patients and operative findings are presented in Table 1.

There was no recurrence, and TSH occurrence during the follow-up period of 50.5 months. Complications occurred in 4 (17.4\%) of the patients. One patient (4.3\%) had symptomatic seroma and required aspiration twice on the $8^{\text {th }}$ and $10^{\text {th }}$ weeks. Three patients (13\%) had chronic pain, all at the same region. Oral analgesics were sufficient, clinical improvement was observed about 4 months following surgery, and no additional intervention was required.

Following the revision and avoiding transabdominal sutures to position the mesh, no complaint of chronic pain was observed, and the difference was statistically significant between the groups $(p<0.05)$. Comparison of the groups is shown in Table 2 Mean follow-up time was significantly higher in Group 1 - $56.6 \pm$ 5.1 months vs. $46.5 \pm 4.8$ months $(p<0.001)$. There was no statistically significant difference regarding age, sex, BMI, smoking, comorbid disease, region, TSH occurrence time, defect size, mesh size, operative time, number of previous operations, and mean hospital stay.

\section{DISCUSSION}

Incisional hernias remain one of the major complications following abdominal surgery with a high ratio $(12,13)$. TSH incidence is rare in comparison with incisional hernias following conventional surgery (10-12). However, the number of TSH has increased due to the high ratio of laparoscopic surgery. Although the exact incidence of lateral sided TSH in our department is unknown, 743 patients have undergone laparoscopic surgery (LAHR, colorectal surgery, bariatric surgery, splenectomy, and adrenalectomy) at the same interval, and 9 (1.2\%) of these patients have been admitted with lateral sided TSH-operations without 10 $\mathrm{mm}$ trocar entry located laterally to the rectus muscle, such as laparoscopic cholecystectomy, TAPP, appendicectomy and remaining operations, were excluded. Following the division of branches in our department, laparoscopic approach has become the first choice of treatment for incisional hernias in the division of hernia surgery, and laparoscopic repair has been used initially for all patients with TSH. Umbilicus was the most common localization and most of the cases with midline localization had a fascial defect under $3 \mathrm{~cm}$ in our series. Open approach for exploration and to repair the edges of the aponeurosis with slight enlargement of the skin incision could be applicable for most of the cases with midline localization in our daily practice. Also, a simple mesh repair could be adequate for this type of hernias (9). All existing reasons led us to abandon laparoscopic approach for TSH with midline localization following initial cases. On the other hand, most of the cases with lateral sided TSH had a fascial defect of $3 \mathrm{~cm}$ or more and content of a sliding colon segment with adhesions was present -due to proximity- in the 
Table 2. Comparison of the groups

\begin{tabular}{|c|c|c|c|}
\hline & Group $1(n=9)$ & Group $2(n=14)$ & $\mathrm{p}$ \\
\hline Age & $48.6 \pm 10.9$ & $52.3 \pm 9.9$ & 0.504 \\
\hline Sex (female/male) & $9(39.1 \%) / 0$ & $10(43.5 \%) / 4(17.4 \%)$ & 0.127 \\
\hline BMI $\left(\mathrm{kg} / \mathrm{m}^{2}\right)$ & $30.8 \pm 5.3$ & $30.5 \pm 4.5$ & 0.975 \\
\hline Smoking & 0 & $3(13 \%)$ & 0.253 \\
\hline Comorbid disease & $6(26.1 \%)$ & $11(47.8 \%)$ & 0.643 \\
\hline Region (right/left) & $6(26.1 \%) / 3(13 \%)$ & $6(26.1 \%) / 8(34.8 \%)$ & 0.4 \\
\hline TSH occurrence time (month) & $5.6 \pm 2.6$ & $6.4 \pm 1.9$ & 0.504 \\
\hline Follow up time (month) & $56.6 \pm 5.1$ & $46.5 \pm 4.8$ & $<0.001$ \\
\hline Defect size $\left(\mathrm{cm}^{2}\right)$ & $21.1 \pm 13.2$ & $13.1 \pm 10.9$ & 0.064 \\
\hline Mesh size $\left(\mathrm{cm}^{2}\right)$ & $225 \pm 64.9$ & $216.4 \pm 55.7$ & 0.765 \\
\hline Operative time (min) & $54.2 \pm 7.6$ & $49.8 \pm 7.1$ & 0.175 \\
\hline Number of previous operations & $2.3 \pm 1.4$ & $1.9 \pm 1.4$ & 0.296 \\
\hline Hospital stay (day) & 1 & 1 & 1.0 \\
\hline \multicolumn{4}{|l|}{ Complications } \\
\hline Seroma & - & 1 & 1.0 \\
\hline Chronic pain & 3 & - & $<0.05$ \\
\hline
\end{tabular}

hernia sac for most of the cases (Figure 2). Disintegrated fibers of the muscles with blunt dissection and insufficient closure due to insufficient identification of lateral borders of the incision have been found to be associated with lateral sided trocar site hernia (12). Considering the methods to prevent lateral sided TSH occurrence, there is a requirement of an extended skin incision to repair disintegrated fibers of muscles. In addition, there is a requirement of an extended skin incision to repair disintegrated fibers of muscles in case of open approach for lateral sided TSH (12).

Obesity, age, defect size, smoking or an asymptomatic hernia could be the reasons not to operate for some surgeons and also, some surgeons refrain from laparoscopic repair concerning preexisting comorbidities (15). All of the patients were admitted with symptoms within 12 months - following laparoscopic surgery - in our series. Depending on recent time and type of the previous operation, we believe that all patients could undergo laparoscopic repair for TSH. Lambertz et al. have reported an extensive series of TSH with a recurrence rate of $9 \%$ and $3 \pm 4$ days of mean hospital stay following conventional repair (7). In addition, Kwon et al. have reported a recurrence rate of 29.4\% following TSH repair (8). Although it is not a scientific data, we should point out a statement for our series: patients with TSH following laparoscopic hernia repair are stressful to the possibility of recurrence, and it is the main issue that these patients focus on. The absence of recurrence and 1 day of mean hospital stay in our series could be supportive findings for laparoscopic repair of TSH. TSH occurrence has been reported higher in obese patients before $(3,4,12)$. Lambertz et al. have reported that patients with mesh repair had higher BMI and mean operative time $-32 \pm 9$ of BMl and $83 \pm 47$ minutes of mean operative time (7). Technical difficulties could explain this condition. Most of the cases were obese or overweight in our series. Despite a similar level of BMI, mean operative time seems to be shorter in our series $-30.7 \pm 4.8$ of $\mathrm{BMl}$ and $51.5 \pm 7.4$ minutes of mean operative time. Regarding the technical difficulties in obese patients, laparoscopic repair of TSH could be a choice of treatment to shorten mean operative time.

Chronic pain was the major complication, and 3 cases had complaints about pain for more than 3 months in our series. All patients had the same complaint at the same region - around the superior edge and near costal margin of the transabdominal suture. Although oral analgesics were sufficient, depending on patients' complaints around the transabdominal sutures, we avoided using transabdominal sutures to position the mesh for subsequent cases. The absence of chronic pain in the revised group and the statistically significant difference was supportive to avoid using transabdominal sutures in lateral sided TSH patients. Furthermore, there was no recurrence or an unexpected complication in Group 2 patients due to the absence of transabdominal sutures on follow-up. Observational design was the major limitation of our study, patients in Group 1 were the first cases and the difference between mean follow-up time was a result of this condition. In spite of the statistically significant difference, all of the patients were followed for more than 36 months in our series, and mean follow-up time of 46.5 months 

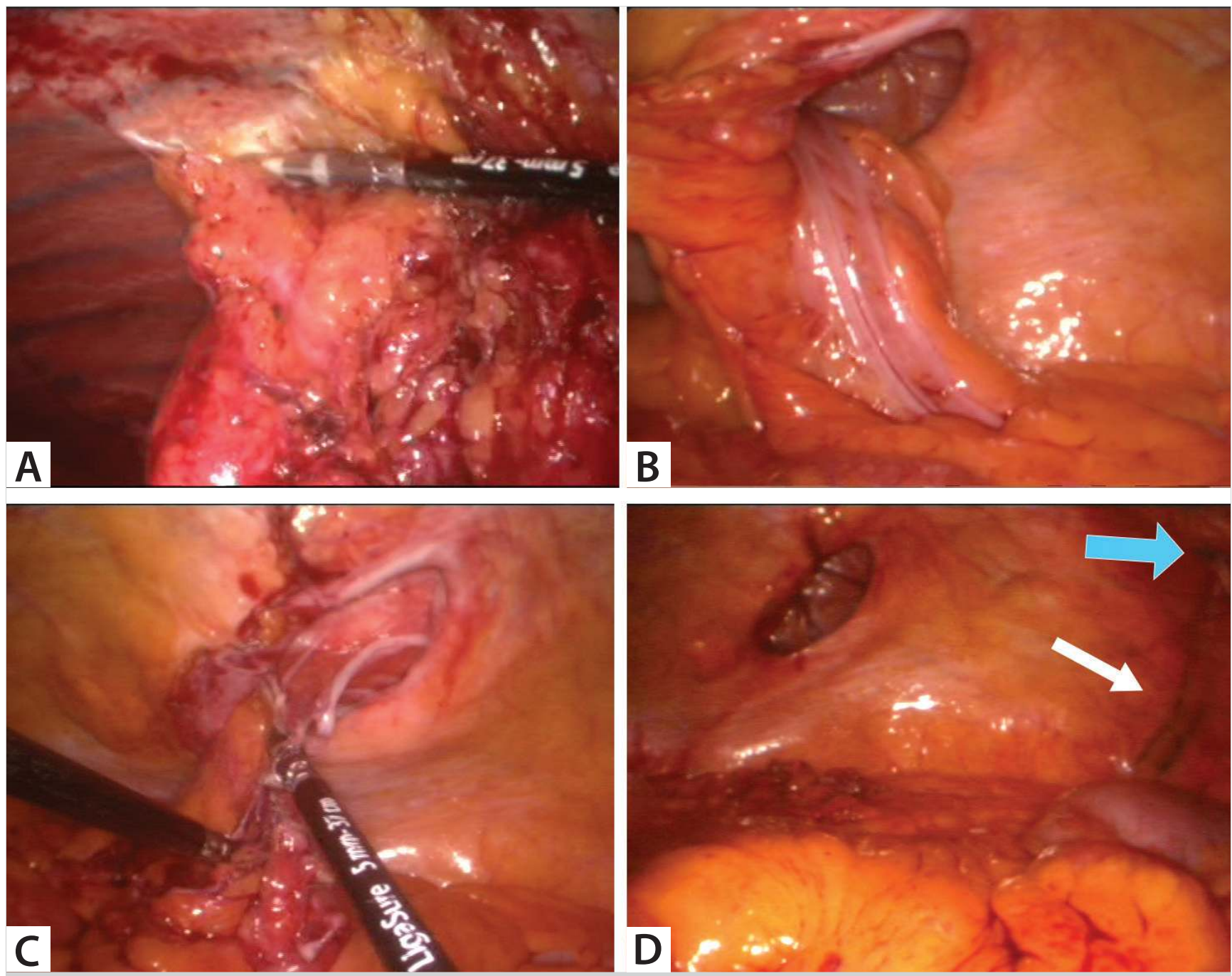

Figure 2. Left-sided trocar site hernia following laparoscopic hernia repair a. Adhesiolysis of previous laparoscopic hernia repair, b. Sliding colon segment, c. Reduction of colon segment, $d$. Appearance following adhesiolysis and reduction (blue arrow indicates the edge of the previous mesh, white arrow indicates inferior epigastric vessels).

in Group 2 patients could be considered as a notable duration from most of the studies in the literature. Kwon $\mathrm{YH}$ et al. have reported the mean duration between TSH repair and first recurrence as 32 months - in a range between 20-49 months - and have recommended examination annually for the first two years to detect recurrence (8). Due to lack of recurrence following LRTSH and lack of lateral sided TSH occurrence after postoperative year 1, we can recommend an examination for the first year and longer intervals more than a year to prevent unnecessary controls.

\section{CONCLUSION}

In conclusion, previous laparoscopic surgery indicates the lack of obstacle in laparoscopic repair of TSH, and laparoscopic repair of lateral sided TSH can be considered as the first option in treatment. Shorter mean operative time in obese patients, lack of recurrence, and shorter mean hospital stay in our series support this view. As a technical detail, the use of transabdominal sutures should be avoided to prevent chronic pain in LRTSH.

Ethics Committee Approval: Ethics committee approval was received for this study from Kartal Dr. Lütfi Kırdar Training and Research Hospital Clinical Research Ethics Committee (2018/514/139/2).

Peer-review: Externally peer-reviewed.

Author Contributions: Concept - H.E.S., K.Ç.; Design - H.E.S.; Supervision H.E.S., K.C.; Materials - H.E.S., K.Ç.; Data Collection and/or Processing - H.E.S., K.Ç.; Analysis and Interpretation - H.E.S., K.Ç.; Literature Review - H.E.S.; Writing Manuscript - H.E.S.; Critical Reviews - H.E.S.

Conflict of Interest: The authors have no conflicts of interest to declare.

Financial Disclosure: The authors declared that this study has received no financial support. 


\section{REFERENCES}

1. Boldó E, Perez de Lucia G, Aracil JP, Martin F, Escrig J, Martinez D, et al. Trocar site hernia after laparoscopic ventral hernia repair. Surg EndosC 2007; 21: 798-800. [CrossRef]

2. Moran DC, Kavanagh DO, Sahebally S, Neary PC. Incidence of early symptomatic port-site hernia: a case series from a department where laparoscopy is the preferred surgical approach. Ir J Med Sci 2012; 181: 463-6. [CrossRef]

3. Erdas E, Dazzi C, Secchi F, Aresu S, Pitzalis A, Barbarossa M, et al. Incidence and risk factors for trocar site hernia following laparoscopic cholecystectomy: a long-term follow-up study. Hernia 2012; 16:431-7. [CrossRef]

4. Comajuncosas J, Hermoso J, Gris P, Jimeno J, Orbeal R, Vallverdu H, et al. Risk factors for umbilical trocar site incisional hernia in laparoscopic cholecystectomy: a prospective 3-year follow-up study. Am J Surg 2014; 207: 1-6. [CrossRef]

5. Armañanzas L, Ruiz-Tovar J, Arroyo A, Garcia-PecheP, Armañanzas E, Diez $M$, et al. Prophylactic mesh vs. suture in the closure of the umbilical trocar site after laparoscopic cholecystectomy in high-risk patients for incisional hernia. A randomized clinical trial. J Am Coll Surg 2014; 218: 960-8. [CrossRef]

6. Chatzimavroudis G, Papaziogas B, Galanis I, Koutelidakis I, Atmatzidis $S$, Evangelatos $P$, et al. Trocar site hernia following laparoscopic cholecystectomy: a 10-year single center experience. Hernia 2017; 21: 925-32. [CrossRef]
7. Lambertz A, Stuben BO, Bock B, EickhoffR, Kroh A, Klink CD, et al. Portsite incisional hernia - A case series of 54 patients. Ann Med Surg 2017; 14: 8-11. [CrossRef]

8. Kwon YH, Choe EK, Ryoo SB, Kim JK, Park KJ. Long-term surgical outcome of trocar site hernia repair. Am Surg 2017; 83: 176-82. [CrossRef]

9. PawlakM, BuryK, Śmietański M. The management of abdominal wall hernias - in search of consensus. Wideochir Inne Tech Maloinwazyjne 2015; 10: 49-56. [CrossRef]

10. Helgstrand F, Rosenberg J, Bisgaard T. Trocar site hernia after laparoscopic surgery: a qualitative systematic review. Hernia 2011; 15: 11321. [CrossRef]

11. Owens M, Barry M, Janjua AZ, Winter DC. A systematic review of laparoscopic port site hernias in gastrointestinal surgery. Surgeon 2011; 9: 218-24. [CrossRef]

12. Sikar HE, Cetin K, Eyvaz K, Altin O, Kaya S, Gokceimam M, et al. Lateral sided trocar site hernia following laparoscopic hernia repair: results of a long-term follow-up. Hernia 2019; 23: 101-6. [CrossRef]

13. Sikar HE, Cetin K, Eyvaz K, Kaptanoglu L, Kucuk HF. Laparoscopic repair of large suprapubic hernias. Wideochir Inne Tech Maloinwazyjne 2017; 12: 245-50. [CrossRef]

14. Bhandarkar DS, Katara AN, Shah RS, Udwadia TE. Transabdominal preperitoneal repair of port-site incisional hernia. J Laparoendosc Adv Surg Tech A 2005; 15: 60-2. [CrossRef]

15. Nieuwenhuizen J, Kleinrensink GJ, Hop WC, Jeekel J, Lange JF. Indications for incisional hernia repair: an international questionnaire among hernia surgeons. Hernia 2008; 12: 223-5. [CrossRef]

\title{
ORIJINAL ÇALIŞMA-ÖZET
}

Turk J Surg 2020; 36 (3): 278-283

\section{Lateral yerleşimli trokar yeri fıtıklarının laparoskopik onarımı}

\author{
Hasan Ediz Sıkar ${ }^{1}$, Kenan Çetin ${ }^{1}$ \\ ${ }^{1}$ Dr. Lütfi Kırdar Kartal Eğitim ve Araştırma Hastanesi, Genel Cerrahi Kliniği, Istanbul, Türkiye
}

\section{ÖZET}

Giriş ve Amaç: Trokar yeri fıtığının (TYF) onarımı az sayıda çalışmada bildirilmiştir. TYF çoğunlukla küçük ve göbek bölgesinde yerleşimlidir. Laparoskopik onarım, geniş defektler ve yama onarımı gerektiren lateral yerleşimli TYF'ler için seçenek olabilir. Çalışmamızda laparoskopik onarım uygulanan TYF'lerinde (LOTYF) uzun dönem takip sonuçlarımızı sunmayı amaçladık.

Gereç ve Yöntem: Mart 2013-Temmuz 2015 tarihleri arasında LOTYF uygulanan 23 hasta çalışmaya dahil edildi. Illk 9 hastaya yamanın dört kenarından 2/0 prolen transabdominal dikiş uygulandı (Grup 1). Grup 1'deki 3 hastada beklenmeyen kronik ağıı komplikasyonu gelişmesi nedeniyle sonraki hastalarda ameliyat yöntemi değiştirilerek yamanın pozisyonu için transabdominal dikiş kullanılmadı (Grup 2).

Bulgular: Ortalama 50,9 yaşında, $19(\% 82,6)$ kadın ve $4(\% 17,4)$ erkek hastaya laparoskopik onarım uygulandı. Yöntem değişikliği sonrasında transabdominal dikiş uygulanmamasını takiben hiçbir hastada kronik ağrı şikayeti gözlenmedi ve gruplar arasında istatistiksel açıdan anlamlı fark saptandı $(p<0,05)$.

Sonuç: Geçirilmiş olan laparoskopik cerrahi prosedür, LOTYF uygulanmasına engel bir durum olmadığını göstermektedir. Bu nedenle LOTYF tedavi için ilk seçenek olarak değerlendirilebilir. Obez hastalarda ameliyat süresinin kısa olması, nüks izlenmemesi bu görüşümüzü destekler niteliktedir. LOTYF hastalarında, transabdominal dikişten, olası kronik ağıı şikayetinin önlenmesi için kaçınılmalıdır.

Anahtar Kelimeler: Insizyonel fıtık, laparoskopi, cerrahi yama

Doi: $10.47717 /$ turkjsurg.2020.4447 